\title{
LUT
}

Lappeenranta

University of Technology

\section{Environmental Impacts and Sustainability of Low-Value Roach Fish When Used as Food}

Uusitalo Ville, Panapanaan Virgilio, Vallas Paavo, Kuokkanen Anna, Koistinen Katariina

\author{
This is an Final draft \\ version of an article \\ published by Elsevier \\ in Journal or Cleaner Production
}

DOI: $\quad 10.1016 /$ j.jclepro.2018.09.047

Copyright of the original publication: () 2018 Elsevier Ltd.

Please cite the publication as follows:

Uusitalo, V., Panapanaan, V., Vallas, P., Kuokkanen, A., Koistinen, K. ENVIRONMENTAL IMPACTS AND SUSTAINABILITY OF LOW-VALUE ROACH FISH WHEN USED AS FOOD, Journal of Cleaner Production, 204, 693-701 DOI: https://doi.org/10.1016/j.jclepro.2018.09.047

This is a parallel published version of an original article. This version can differ from the original published article. 
1 EMMRONMENTALIMPACTSANDSUSTANABIUTYOFLOW-VALE

2 ROACHRSHWHENUSEASFOOD

3 Ville Uusitalo*a, Virgilio Panapanaan ${ }^{a}$, Paavo Vallas ${ }^{b}$, Anna Kuokkanen ${ }^{a}$, Katariina Koistinen ${ }^{a}$

$4 \quad{ }^{a}$ Lappeenranta University of Technology, School of Energy Systems, Sustainability Science, P.O. Box

$5 \quad 20,53851$ Lappeenranta, Finland

6 balto University, School of Chemical Technology, Environmental management, P.O. Box 20, 00076

7 Aalto, Espoo, Finland

8

$9{ }^{*}$ Corresponding Author. Current address: Lappeenranta University of Technology, P.O. Box 20,

1053851 Lappeenranta, Finland. Tel.: +358 40586 4486, fax: +358 5621 6399, E-mail:

11 ville.uusitalo@lut.fi

Abstract

One of the major global environmental challenges is the overuse of nutrients and related eutrophication problems. Specifically in Finland, the roach fish population is rapidly increasing in eutrophic water systems. Currently roach fish does not have economic value, and it is mainly composted despite the fact that it could provide a direct protein source for human needs. This paper assumes that new business could be established by removing roach fish from eutrophic water systems and using them as a protein source for human consumption. Removing roach fish directly removes nutrients and indirectly impacts the vicious cycle of eutrophication. This paper assesses different environmental sustainability perspectives of roach fish removal and utilization. It also aims to present different environmental impacts on the planetary boundary framework. The research is carried out using life cycle assessment methodology.

Based on the results, the use of roach fish as a protein source would help in returning to a safe operational zone in biochemical flows. Phosphorous removal with roach fish is $5.8(1.9-10.3) \mathrm{g} \mathrm{kg}^{-1}$ while nitrogen removal is $28.4(26.4-30.4) \mathrm{g} \mathrm{kg}^{-1}$. However, the production has also climate change impacts which are $2.9-5.2 \mathrm{kgCO}_{2 \mathrm{eq}} \mathrm{kg}^{-1}$ roach protein. Nevertheless, the climate change impacts are 12-57 times lower than positive impacts on eutrophication.

Different environmental impacts are assessed regarding whether or not they help to avoid crossing planetary boundaries. Roach fish should be marketed especially for green consumers, and creating new markets for roach fish could also help in eutrophic lake restoration projects. Additionally, new business could be created from nutrient offsetting by roach fish removal.

Roach removal from eutrophic water systems and use as food helps in returning to a safe operational zone in biochemical flows and the positive impacts are far greater than the negative impacts on climate change from fishing and fish processing.

37 Key words: fish, life cycle assessment, carbon footprint, environmental impact, nutrient offsetting, 38 eutrophication 


\section{Introduction}

Since the Anthropocene era, human economic and development activities have led to the crossing of various boundaries of ecological systems and services and surpassing of the limits of safe operation (Rockström et al., 2009; Steffen et al., 2015). Rockström (2009) has highlighted that agriculture and food production have significantly escalated many of these problems. The problems may increase in the future due to a growing global demand for food and shift towards more protein intensive nutrition (Nelleman et al., 2009).

Biochemical flows of nitrogen and phosphorous are exceeding the safe operational zone due to the use of fossil energy based nitrogen and mineral phosphorous fertilizers in intensive agriculture (Steffen et al., 2015). The run-off of fertilizers in the water systems leads to eutrophication. Eutrophication impacts entire aquatic ecological entities and their dynamics. One of the most notable effect of eutrophication is algal bloom, but there are also many other impacts on entire water ecosystems (Friedl, 2017). In Finland, eutrophication in lakes and in the Baltic Sea is one of the reasons for biodiversity loss. According to Kontula and Raunio (2013), approximately half of the marine, coastal and inland water biotopes in Finland have been endangered due in full or in part to eutrophication. Additionally, the number of endangered birds in Finland is increasing because of eutrophication (Tiainen et al., 2015).

In eutrophic water systems, some fish species, such as the common roach (Rutilus rutilus), grow very rapidly because they find the eutrophic conditions of the water very favorable for their food and reproduction (Niinimäki and Niinimäki, 2008). Roach fish feed voraciously on algae and zooplanktons (Mäkinen, 2008). Zooplanktons, in turn, feed on phytoplanktons. Thus, the reduction of zooplanktons leads to the growth of the phytoplankton population particularly at the bottom of the water system (Ruuhijärvi, 2014; Furman et al., 2014). This reduces visibility in the water and increases the phytoplankton biomass at the bottom of the water system. Reduced visibility leads to a lack of sunlight in deeper water layers and makes catching more difficult for predatory fish. The increased biomass in water systems slowly degrades, consuming oxygen. The lack of oxygen leads to the release of P from sediments, thus intensifying the eutrophication (Reed et al., 2011; Furman et al., 2014). Roach fish also dig bottom sediments in search for nutrition, which may release phosphorous.

Because of their low economic value, roach fish are typically discarded, composted, or used as feed for fur animals despite the fact that they could be used as a protein source also for human needs. There are no clear reasons why roach fish are not currently valued as food even though they have been an important source of protein in the past (Haggren et al., 2015). Roach fishing is not economically viable if there is no price for the fish meat. Therefore, roach removal processes from water systems require economic support from society. From an economic perspective, the remote location of water systems compared to fish processing facilities poses another challenge. In addition, roach fish are usually removed within a short period of time in certain water systems, and therefore, the locations of roach fish biomass change constantly.

Since sustainability agendas have defined and required new approaches to manage and keep the integrity of our ecological resources and to obtain more value-added products, the roach fish is an interesting case. It can be assumed that roach fish removal improves sustainability in some of the planetary boundary (PB) categories, but there are most likely also negative sustainability impacts in using roach fish as food. 
Thus, assessing the environmental impacts and sustainability of removing roach fish from eutrophic water systems and using them as food are ways to address burden shifting and possible negative environmental impacts. Related to this, Thrane (2006) has conducted a life cycle assessment (LCA) to determine the environmental sustainability of Danish flatfish production. According to his results, fishing and especially fuel consumption has the highest impact on the environment out of the different process stages. Svanes et al. (2011) have compared allocation methods for fishing side flows wherein they found out that the allocation method selection plays an important role in the results. According to Thrane et al. $(2009 \mathrm{~A})$, the fish industry has been able to reduce its environmental burden in the recent past. Thrane et al. (2009B) have shown that the eco-labelling of fish does not include stages after landing and they have suggested that such stages should be included in future development. They further propose that research should focus not just on climate change impacts but also on other environmental impacts.

LCA is an applicable approach to study the environmental sustainability and impacts of a given product. However, on a global scale it is important to understand how a certain product is or is not helping humankind to return to a safe operational zone from the PB perspective. However, there are challenges in combining LCA results and PB frameworks. Previous attempts and suggestions to combine the LCA and PB frameworks have mostly taken a top-down approach. Sundin et al. (2015) have studied and suggested combining a PB framework and LCA by dividing environmental impact reduction targets for different market sectors and products. Ryberg et al. (2016) have brought up the challenges in implementing a PB-based LCA assessment methodology. According to their research, it is especially challenging to model and include earth system processes as impact categories in LCA. Their conclusion is that PB-based LCA impacts assessment would be highly relevant for the environmental sustainability performance assessment of products and systems. Sala et al. (2014) have demonstrated a person-equivalent of a safe operating space, for example, at the national level. Their suggestion is to compare LCA impacts as person-equivalents between different countries globally. Wolf et al. 2017 have made the first attempt to combine LCA and PB frameworks for food companies. They used absolute environmental sustainability assessment (AESA) methods in which the general principle is to compare the environmental footprint of a company with its assigned share of the environmental budget (Wolf et al. 2017). Clift et al. (2017) have recognized a need to develop a practical tool to enable the use of a PB framework for business and public policy. They also demand the allocation of a safe operating space between companies and different sectors. Bjørn et al. (2015) have suggested that to support development within planetary boundaries, a stronger link would be needed between LCA and absolute sustainability indicators. These indicators should include the carrying capacity of the Earth's systems. Bjørn et al. (2016) have demonstrated that it is possible to modify LCA indicators from relative nature to absolute indicators of environmental sustainability. The main challenge of this process is related to uncertainties. Chandrakumar and M cLaren (2018) have compared LCA and PB related environmental sustainability indicators. They found out that the following categories are represented in both approaches: water scarcity, climate related hazards, eutrophication, land-system change, air pollutants and toxic effects, acidification, and ozone depletion. Dong and Hauschild (2017) have conducted a similar comparison, according to which also change in the biosphere integrity/biodiversity was represented in both PB and LCA indicators.

We argue that a simple method is required to present the LCA environmental impacts in the PB framework to support decision-making on the environmental sustainability of products or systems. The aim of this paper is to evaluate the environmental sustainability impacts of roach fish removal from eutrophic water systems and use the fish as a protein source. The aim is also to present LCA 
based environmental sustainability impacts in a PB framew ork to show how roach fish use would help to return towards a safe operational zone. The magnitudes of different impacts are compared to each other using normalization. This is the first attempt to present food production LCA impacts using a PB framework.

\section{Materials and methods}

This paper assesses the environmental impacts of roach use as food using LCA methodology. The results of the LCA are presented in a PB framework to show whether the impacts are positive or negative from a PB safe operating zone perspective and compare the magnitudes of different impacts to each other.

Steffen et al. (2015) have presented an updated version of the PB framework (Rockström et al., 2009) and safe operating space for human societies. The framework identifies nine main categories of the Earth's system boundaries that are critical to the stability of our planet. According to their paper, humans have already crossed the safe boundaries of climate change, biochemical flows ( $N$ and $P$ ), land system change and biosphere integrity (biodiversity). Therefore, this paper focuses on these four areas. However, impacts on biosphere integrity (biodiversity) are only discussed but not assessed using LCA due to a lack of exact measured data. Roach fishing and use may also have other impacts that are not included in this study, such as aerosol emission from energy related processes, ozone layer depletion impacts from cooling devices, and fresh water use from washing processes.

\subsection{Life cycle assessment}

Life cycle assessment (LCA) is a widely employed method for assessing environmental impacts related to a product or a process. The LCA model for assessing the environmental impacts of roach fish production was designed with the GaBi 7.0 software and professional database. The ISO 14040 and ISO 14044 standards were applied as guidelines for the LCA model.

The roach fish production process was streamlined based on the main process steps: fishing, processing, transportation and side flow utilization. The main product of the process is roach fillet, and side flows include e.g. skin, organs and bones. From a methodological perspective, there are a few options for side flow handling in LCA. Because side flows do not have economic value and the main process does not aim to produce side flows, an allocation of environmental impacts between fish meat and side flows cannot be carried out according to ISO standards. There are two main scenarios for side flow handling related to roach production:

1) Side flows are composted in an aerobic process, and the final compost is used for landscaping e.g. in a landfill.

2) Side flows are digested in an anaerobic process and the produced biogas is used in energy production and digestate (containing $\mathrm{N}$ and $\mathrm{P}$ ) in fertilizing.

The first scenario represents the worst case in which compost product is not really used as food production fertilizer due to pathogen risks. This is a possible case e.g. is compost also uses waste water treatment plant sludge. The second scenario is a more desirable case.

To assess the real environmental impacts of side flow use, a system expansion method is utilized based on the instructions of ISO/TR 14049. Figure 1 presents the life cycle of roach production, system boundaries and system expansion scenarios. 
1

2 Figure 1. System boundaries and mass and energy flows in system expansion method for roach side

3 flow utilization in the two scenarios.

5 The functional unit of this study is $1 \mathrm{~kg}$ of roach fish meat. However, the results are also presented for $61 \mathrm{~kg}$ of roach fish protein to make comparison to other studies easier. The following sections present 7 the initial data used in the calculations. The variation in the initial data is presented in parentheses 8 after the basic assumptions. This variation is used in a sensitivity analysis. The aim of the sensitivity 9 analysis is to present the minimum and maximum values for results based on variation in the initial 10 data. There are various applicable methods for environmental impact assessment. In this research environmental impacts are assessed using ILCD and CML approaches in the GaBi software. ILCD methods gives recommended characterization factors for the European context. CML on the other hand is widely used method, which includes eutrophication category. There is difference in eutrophication characterization factors between ILCD and CM L methods and therefore eutrophication impacts are calculated using these two methods to show impact of methodology selection.

Data collection for this study was done using literature. We did go through scientific international literature related to fish LCAs as well as national literate especially related to roach fish fishing and processing. For environmental impact assessment GaBi database data was utilized to support the calculation model. The following chapters explain in detail data selections.

Roach fish is typically harvested with a trawl or seine. Use of a seine consumes less energy than other fishing options because it can be operated by using only a single boat at a close range from the shoreline. According to Helenius (2010) and Schau (2009), diesel consumption in purse seining is approximately $0.10(0.08-0.12) \mathrm{I} \mathrm{kg}^{-1}$ raw fish. Seining can be seen as the most potential fishing method especially in lakes. Fishing in the Baltic Sea, on the other hand, may consume more energy. Diesel combustion is assumed to lead to $87.6 \mathrm{gCO}_{2 \text { eq }} \mathrm{MJ}^{-1}$ emissions (Biograce).

Fish processing (sorting and cleaning) consumes approximately $0.044(0.040-0.050) \mathrm{kWh} \mathrm{kg}^{-1}$ electricity (Silvenius and Grönroos, 2003). The freezing processes require electricity. In small freezers, the electricity consumption is approximately $0.12(0.08) \mathrm{kWh} \mathrm{kg}^{-1}$ (Tan and Culaba, 2009). M uch lower electricity consumption can be achieved in larger processing plants (Tan and Culaba, 2009). However, 
of roach fish is 50 (40-60) \% (Setälä, 2011). It is assumed that a fish processing plant is at a close range to a fishing port and that cleaned fish is transported within a 100 (5-300) km distance to consumers. The following GaBi professional database processes are used in the modeling:

- For electricity production: "Average electricity production in Finland"

- For diesel production: "EU-27 diesel mix at refilling station"

- For transportation: "EURO 4 truck with 12.4 t payload"

- For phosphorus fertilizer production "Global rock phosphate mix with 32,4\% P content"

- For nitrogen fertilizer production "German Liquid ammonia mix for agriculture with $82 \% \mathrm{~N}$ content"

- $\quad$ For natural gas production and use: "Process steam from natural gas in Finland"

There is relatively high variation in $\mathrm{P}$ and $\mathrm{N}$ contents in roach fish. Table 1 presents the $\mathrm{P}$ and $\mathrm{N}$ mass fractions in roach fish from literature. Average values are used in the calculations, but also the variation of values is included in the sensitivity analysis.

Table 1. Phosphorous and nitrogen mass fractions in roach fish based on literature

\begin{tabular}{lll}
\hline $\begin{array}{l}\text { Phosphorus (P) } \\
\mathrm{g} \mathrm{kg}^{-1}\end{array}$ & $\begin{array}{l}\text { Nitrogen (N) } \\
\mathrm{g} \mathrm{kg}^{-1}\end{array}$ & Reference \\
\hline 8.1 & 26.4 & Schrechenbach et al. 2001 \\
10.3 & 30.4 & Schrechenbach et al. 2001 \\
7 & & Ruuhijärvi 2014 \\
1.9 & & Stanek and Janicki 2011 \\
2.2 & & Stanek and Janicki 2011 \\
5.5 & & Karjalainen et al. 1997 \\
Average 5.8 & Average 28.4 & \\
\hline
\end{tabular}

If processing side flows are not composted, peat is assumed to be used in landfilling. The greenhouse gas emissions from peat production are approximately $102 \mathrm{gCO}_{2 \text { eq }} \mathrm{t}^{-1}$ peat (Myllymaa, 2008). If side flows are not directed to the biogas process, natural gas has to be used in energy production and $\mathrm{N}$ and $\mathrm{P}$ fertilizers have to be produced from mineral and fossil sources. Energy production from natural gas has been modeled using the GaBi professional database for Finnish natural gas based thermal energy production. According to Uusitalo et al. (2014A) the global warming potential (GWP) of biogas production from waste flows using mesophilic anaerobic digestion is assumed to be $20 \mathrm{gCO}_{2 \mathrm{eq}} \mathrm{MJ}^{-1}$. Biogas production potential from roach processing side flows are calculated using the following values provided to fish processing waste: total solids content of fish biomass $27 \%$, volatile solid (VS) content of total solids $85 \%$ and methane productivity $520 \mathrm{~m}^{3}$ tvs (Rasi et al. 2012). Composting emissions from a large scale compost process are 68 (60-76) $\mathrm{g} \mathrm{CO}_{2 \text { eq }} \mathrm{kg}^{-1}$ (YTV 2010). It is assumed that a small share of nitrogen in compost and digestate reacts to $\mathrm{N}_{2} \mathrm{O}$ and some carbon reacts to methane causing 0,203 $\mathrm{g} \mathrm{CO}_{2 \text { eq }} \mathrm{kg}^{-1}$ of biomass emissions (IPCC 2006). A basic assumption is that $\mathrm{P}$ and $\mathrm{N}$ in biogas digestate can replace fossil and mineral $P$ and $N$ with 1:1 ratio. Yang and Heijungs (2017) see risks in these types of $1: 1$ perfect substitutions because there may be differences in nutrient plant uptakes. The substitution can be partial or total substitution (Riva et al. 2016). According to Møller et al. (2009) Phopshorus substitution is approximately $100 \%$ but nitrogen substitution can be in some cases only $40 \%$.

Land use requirements for roach fishing are at a low level. Roach fish processing equipment can fit to a sea container thus occupying $13 \mathrm{~m}^{2}$ land area. An additional $20 \mathrm{~m}^{3}$ has been assumed for supporting 
1

processes. It is assumed that $33000 \mathrm{~kg}$ of roach fish could be processed with one processing equipment.

\subsection{Method for presenting LCA impacts in a PB framework}

The following approach is developed to present results from an LCA in the PB framework. First, environmental impacts are assessed using LCA methodology. Then, these impacts are normalized using an applicable normalization method. The LCA impacts are not similar than categories in the PB framework but we have tried to find the most applicable impact categories to present PB impacts. The impacts are defined as positive or negative from the perspective of the PB safe operational zone. Whether the impacts are helping in returning to safe operational zone or not. Next, all the normalized categories are compared to normalized GWP results. The comparison can also be done to other categories but GWP is recommended because it is widely used in sustainability assessments. This selection does not have impacts on conclusions. The comparison to GWP is done using the equation (1):

$$
C_{n}=\frac{N I_{n}}{N I_{G W P}}
$$

, where $\quad$ is relative normalized impact to be presented in the PB framework $\mathrm{NI}$ is a normalized impact $\mathrm{n}$ is a category in the PB framework such as GWP, EP or LU

Finally, the relative normalized results are placed into the PB framework. Figure 3 presents the entire approach.

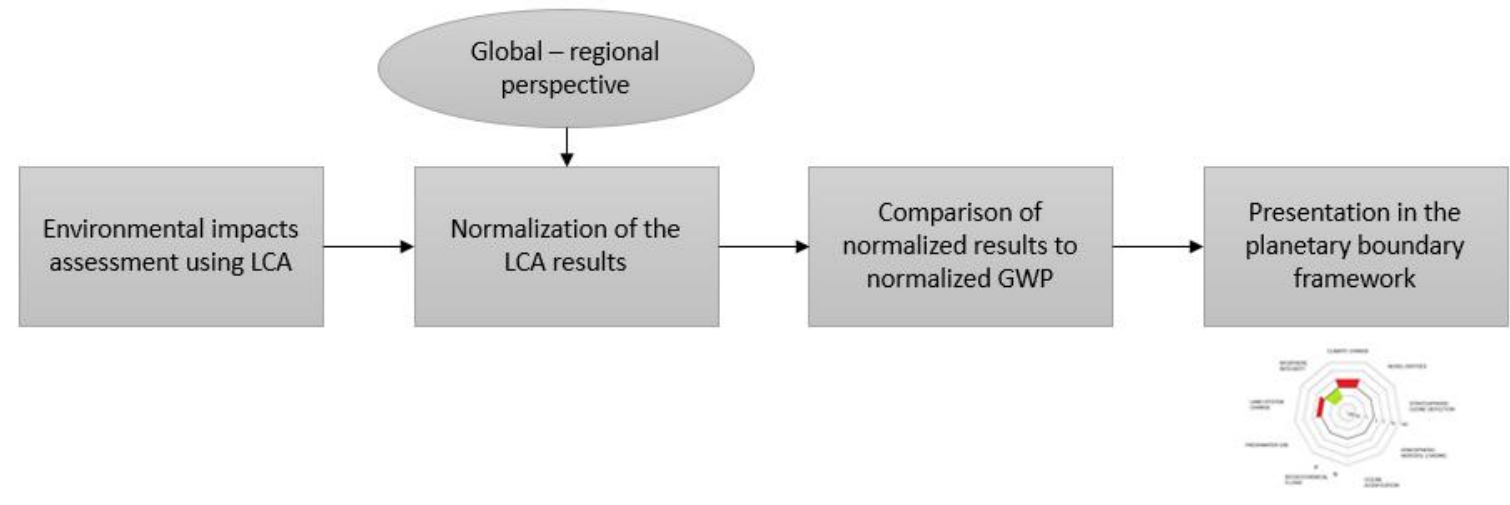

Figure 3: M ethod to present LCA impact assessment results in PB framework.

This paper assesses three environmental impact categories (climate change, biochemical flows and land system change) using LCA. However, it would be possible to do a similar assessment also for other categories. The results are normalized by using CM L 2013 World and ILCD/PEF Pilot normalizations in comparison.

\section{Results and discussions}

\subsection{Life cycle environmental impacts}

Figure 4 presents the GWP impacts of roach fish production using a system expansion method. The figure 4 also presents GWP impact variation based on variation in initial data. The side flow use in 
biogas production leads to significantly lower GWP than composting at a system level. Especially biogas use in energy production instead of fossil natural gas and digestate use to replace fossil nitrogen have significant impacts. GWP reduction by fossil energy and fertilizer production with side flows via biogas production are almost at the same level as the GWP from roach production. The figure 4 presents GWP based on ILCD impact factors and difference to CM L based results were marginal.

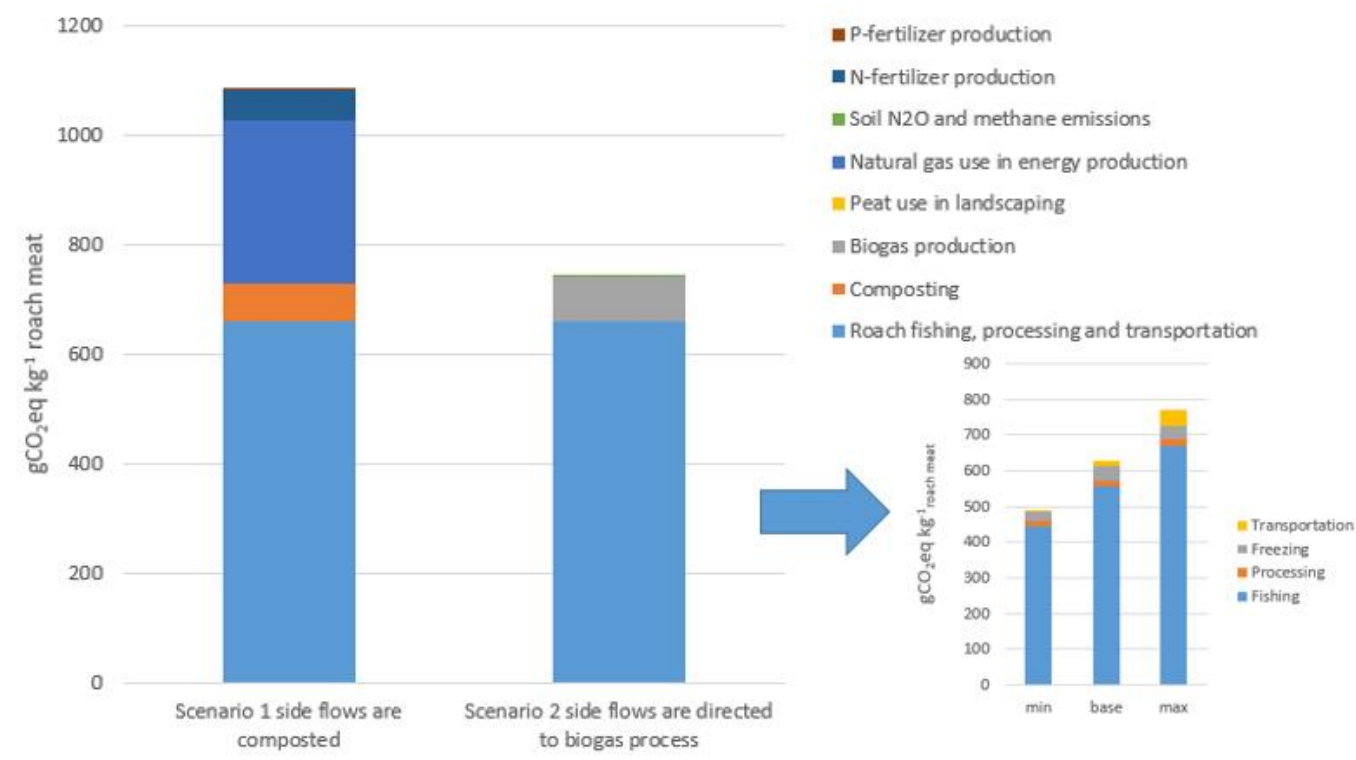

Figure 4. Global warming potential comparison of side flow utilization with composting and biogas scenarios using a system expansion method. Minimum and maximum values are calculated using variation in initial data presented in materials and methods section.

Fishing, and especially fossil diesel consumption, is the most important process step from the GWP perspective. This confirms the results of previous fish related studies by Thrane (2006), Ziegler et al. (2016), Freon et al. (2014), and Laso et al. (2018). In this paper, seining with relatively low energy consumption was chosen as the fishing method. The impacts of fishing could increase if other fishing methods were applied, as has previously been presented by Schau (2009) and Magerholm (2010). Other categories have a relatively small impact on the total GWP. It seems that the easiest way to reduce the GWP of the roach production process could be to use renewable diesel in fishing boats, but this however depends on renewable diesel feedstock selection and possible land use change impacts. By using waste and sideflow feedstock most of the direct land use impacts can be avoided and high greenhouse gas emission reductions are likely. (Uusitalo, et al. 2014B) There may also be other sustainability impacts from biofuel utilization. The construction of equipment was not included in this research, but it can be assumed to have a relatively small impact on the results. According to Freon et al. (2014), equipment construction corresponds to $6 \%$ of fish-related global warming impacts. With the assumption that digestate nitrogen substitutes fossil $\mathrm{N}$-fertilizer with $40 \%$ ratio would lead to $34 \mathrm{gCO}_{2 \text { eq }} \mathrm{kg}^{-1}$ lower emissions in the scenario 1.

The GWP of roach meat production can be further modified to present the GWP for roach protein. The protein mass fraction in the roach meat is approximately $17-20 \%$. Nijdam et al. (2012) have collected data on protein GWPs from various literature sources. Figure 5 compares the results of this 
1 research to data collected in other studies. The GWP of roach protein varies from 2.9 to $5.2 \mathrm{kgCO}_{\text {2eq }}$

$2 \mathrm{~kg}^{-1}$.

4 Table 2. Comparison of global warming potentials of roach fish protein to other protein sources. The 5 table present the variation between the minimum and maximum values presented in literature. 6 (Nijdam et al., 2012; Clune, S. et al., 2017; Laso, J. et al., 2018; Winther et al., 2009; Vazquez-Rowe, I., 7 2017)

\begin{tabular}{ll}
\hline Protein source & $\mathrm{GWP} \mathrm{kgCO}_{2 \mathrm{eq}} \mathrm{kg}_{\text {protein }}{ }^{-1}$ \\
\hline Beef & $45-643$ \\
Pork & $20-55$ \\
Poultry & $10-30$ \\
Eggs & $15-42$ \\
Sheep & $51-750$ \\
Milk & $28-43$ \\
Cheese & $28-68$ \\
Seafood from fisheries & $4-540$ \\
Seafood from aquaculture & $4-75$ \\
Wild fish & $5-70$ \\
Meat substitutes containing egg- or milk protein & $17-34$ \\
Meat substitution 100\& vegetal & $6-17$ \\
Pulses, dry & $4-10$ \\
Roach & $2-5$ \\
\hline
\end{tabular}

8

9 Table 2 shows that the use of roach fish protein is better in terms of the GWP than any of the compared 10 protein sources. This can be explained primarily by the fact that fish growing does not have any 11 impacts, as it is regarded as a natural process. Also previous wild fish GWP studies have shown low 12 GWPs, as Table 2 shows. For other protein sources, the cultivation and growing processes typically 13 have the highest impacts on GHG emissions. Therefore, roach provides an option to produce food 14 protein with minimal GWP. Comparison of results from different LCA studies are however not always 15 straightforward, because different methodological selections such as system boundary setting may 16 have been applied.

17 Figure 5 presents eutrophication potential (EP) using three different approaches. Phosphorous 18 removal with roach fish is 5.8 (1.9-10.3) g kg-1 while nitrogen removal is $28.4(26.4-30.4) \mathrm{g} \mathrm{kg}^{-1}$. There 19 is no significant difference in the results based on chosen impact assessment method. System 20 expansion approach show that side flow utilization option does not have a significant impact on the 21 results because $\mathrm{N}$ and $\mathrm{P}$ are returned to environment via compost or digestate. Other life cycle steps 22 have also minimal impacts on EP. 


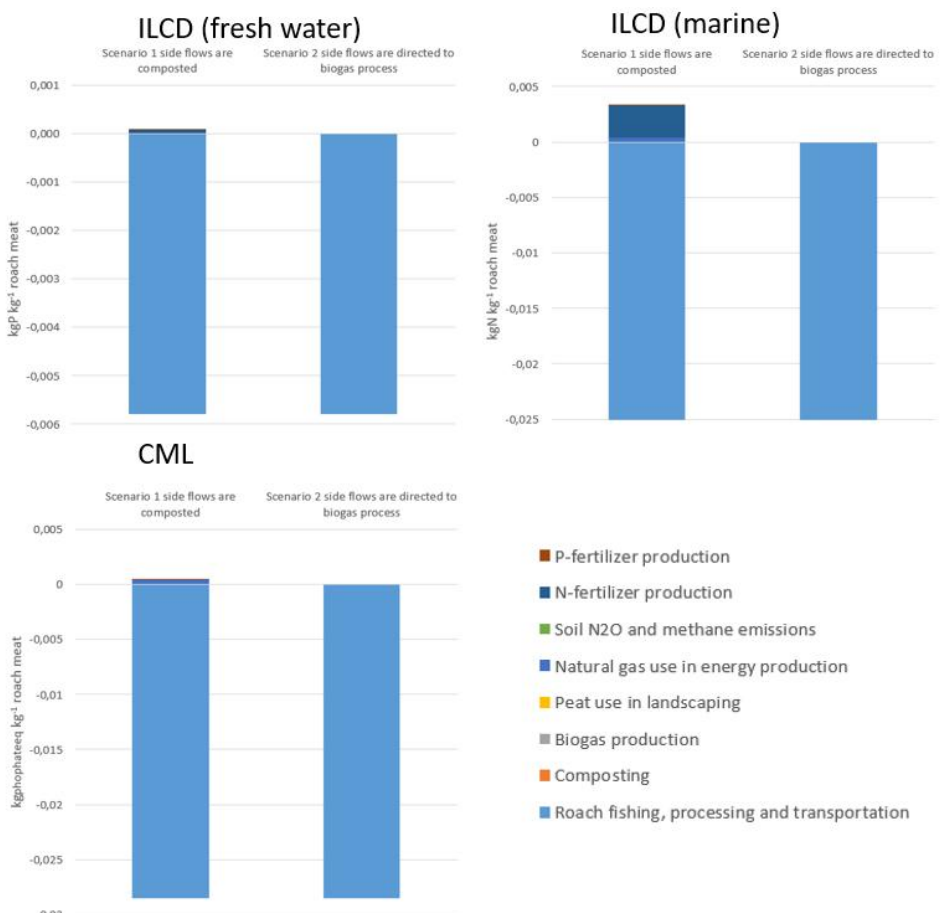

2 Figure 5. Eutrophication potential comparison of side flow utilization with composting and biogas 3 scenarios using a system expansion method.

4 CML 2013 World normalization results to 1.51E-14 (minimum 1.17E-14 and maximum 1.85E-14) in 5 GWP and -1.8E-13 (minimum 1.07E-13 and maximum 2.80E-13) in EP. ILCD/PEF Pilot normalization in 6 person equivalents leads to 6,91E-5 in GWP, -0.00392 in EP fresh water and -0.00149 in EP marine. 7 These normalized results are displayed in the PB framework for $1 \mathrm{~kg}$ roach meat. 

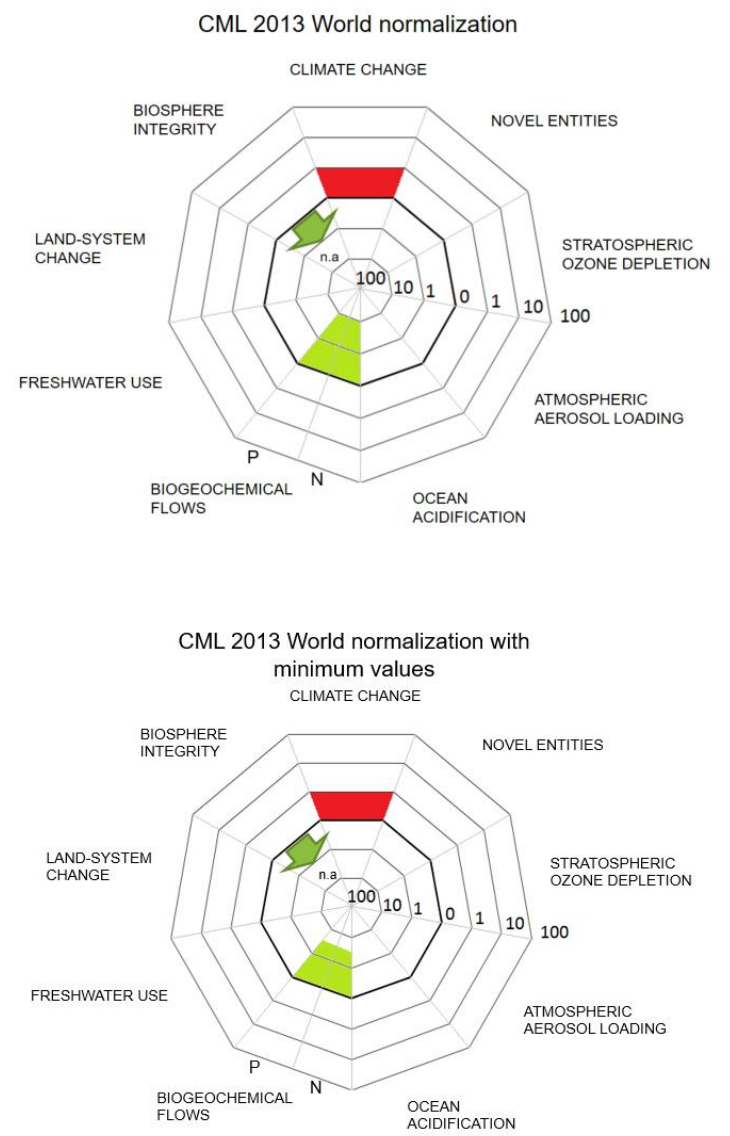
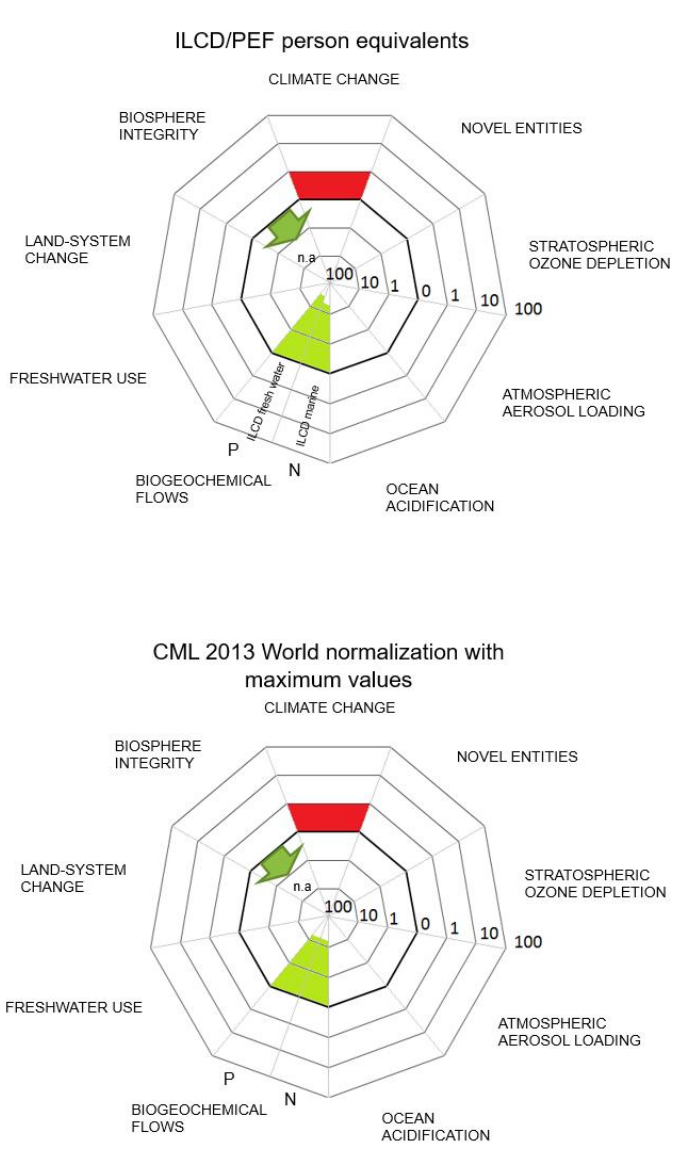

Figure 6. Normalized environmental impacts from LCA of roach fish production and use as food are presented in the PB framework. The impacts have been normalized using CML 2013 World data and ILCD/PEF person equivalents. Minimum and maximum values have also been calculated for CM L 2013 World data normalization using minimum and maximum GWP and nutrient removal.

The positive impact on EP is 6-57 times higher than the negative impact on global warming. Roach fish processing may have global warming impacts, but the impacts are lower than those of other protein sources. Roach fish processing helps in returning to the safe operating zone of biogeochemical flows by removing $\mathrm{P}$ and $\mathrm{N}$ from water systems. Roach fish removal also impacts the biosphere integrity by reducing eutrophication, which is one of the reasons behind biodiversity problems; this, however, was not studied in detail. Land use required for one $\mathrm{kg}$ roach processing is approximately $0.007 \mathrm{~m}^{2}$. There is relatively high uncertainty related to this due to lack of exact data. However this is impact is minimal compared to GWP and EP categories. It would be possible to present quantitative impacts along with the normalized results because some information is always lost when impacts are normalized.

Dong \& Hauschild (2017) show that both LCA and PB include indicators in the same categories but they do not try to combine these two approaches. Clift et al. (2017) have recognized a need to develop a practical tool to help decision making for reaching safe operational zone in PBs. To allocate fair shares in safe operational zone is challenge. Our approach does not require allocation of safe operational zone because it just shows the direction and relative magnitudes of each impacts. Bjørn \& Hauschild (2015) and Bjørn et al. (2015) presents a need for link between LCA and ecosystem carrying capacities. To recognize carrying capacities for different ecosystems and different impacts is however challenging. Therefore the approach presented is this paper is much more easier to carry out because comparison is not done to carrying capacities. 
1

All food systems have various environmental impacts. Some may be positive but others are negative. For example meat production with natural grazing may have positive biodiversity impacts in certain regions. Using the approach presented in this paper could help to recognize different impacts related to food processes. However, this approach should be developed and standardized for comparative research.

\subsection{Business opportunities}

Roach fish meat utilization has several environmental benefits and can thus be seen as a sustainable food innovation. For now, it is still a niche business, but more extensive utilization of roach can significantly contribute to sustainability. In fact, new technologies often require protected niches to shield them from mainstream selection pressure until they are strong enough to compete with mainstream solutions (Geels and Schot, 2010). The new innovation is able to develop, scale up, and eventually destabilize the status quo within niches (Huijben et al., 2016).

Because of the sustainability benefits, roach fish meat products may potentially attract green consumers. Consumers who are motivated by green values and ethics are typically referred to as green consumers. Green consumers mainly base their decisions on ecological values and are willing to pay extra if the product or service meets their idea of an ethical product or service (Van Doorn and Vernhoef, 2015; Whitson et al., 2014). For example, Hughner (2007) has examined how a significant number of consumers (67\%) express a positive attitude towards purchasing organic food products. In addition, Defra (2006) has concluded that $30 \%$ of consumers in the UK have concerns related environmental issues. However, positive attitudes towards sustainability and green products and environmental concerns translate rarely into actions since the market share of green products remains around $1-3 \%$ of the entire market (Bray, Johns and Killburn, 2011). Although the actual purchasing of environmentally conscious products is still limited, consumers have the potential to prevent or decrease environmental damage by purchasing green products (Joshi and Rahman, 2015). Hence, green consumers should not be neglected since they are capable of altering the status quo in the food market.

Even though roach fish products might at first attract only the green consumer segment, roach fish has the potential to gain consumers from other consumer segments, which consequently can open the pathway to altering the status quo and eventually gaining strong sustainability. In addition to sustainability benefits, roach fish products are also relatively cost-efficient. The end products from roach fish meat can be significantly more affordable compared to other fish meats, i.e. salmon or pikeperch. Consequently, roach fish meat products can create customer value by price competition among customers who are not labeled as green consumers.

An additional economic tool to increase roach fishing could be voluntary nutrient trade. For example, grain producers could eliminate their nutrient run-off by buying nutrient removal certificates from fisheries. Additional business based on income from nutrient removal could also boost the roach food business. This type of approach has been tested in the Baltic Sea Region in the NutriTrade project (NutriTrade).

Commercial marine fishing in Finland in 2014 led to a roach fish catch of 800 tons, and commercial inland fishing in 2015 to one of 500 tons (LUKE, 2015). This would remove approximately 7.5 tons of $\mathrm{P}$ and 37.0 tons of $\mathrm{N}$. To reduce $\mathrm{P}$ amounts in water systems, approximately $50-200 \mathrm{~kg} \mathrm{ha}^{-1}$ could be 
1 harvested from Finnish lakes (Sarvilinna, 2010). Svensson (2014) has calculated the roach fish removal 2 potential in five Swedish lakes and showed that the fish removal potential varied from 21 tons to 78 tons, which would in total result in 1.1-1.5 tons of $\mathrm{P}$ and 4.4-5.9 tons of $\mathrm{N}$ removal.

The use of roach fish as food from eutrophic water systems helps to reduce eutrophication directly and possibly biodiversity loss indirectly. However, roach use leads to global warming impacts but these impacts are at a low level especially compared to other possible protein sources presented in the literature. Normalized results from a LCA environmental impact assessment for GWP and eutrophication can be presented in a planetary boundary framework. This may help to determine the magnitude and direction of different environmental impacts and help in decision making situations. This kind of simple tool can be applicable also for business operators who need to understand impacts of their business. The magnitude of the positive impact on eutrophication from roach use are at a higher level than negative impacts on global warmings. The method to combine LCA results and PB framework should be further developed and tested also for other environmental impacts.

Similar processes are likely taking place in other regions where agriculture is intense and nutrients are utilized extensively. Some species are growing in the changing ecosystem due to eutrophication. There may be utilization opportunities similar to roach fish in Finland.

Acknowledgments

This paper is a part of the REISKA project funded by the EU Regional Development Fund

\section{References}

BioGrace. Harmonized calculations of biofuel greenhouse gas emissions in Europe. http://www.biograce.net/ content/ghgcalculationtools/overview

Bjørn, A., Diamond, M., Owsianiak, M., Verzat, B., Hauschild, M., Z. 2015. Strengthening the link between life cycle assessment and indicators for absolute sustainability to support development within planetary boundaries. Environmental Science \& Technology, 49, 6370-6371 environmental sustainability in life cycle assessment. Ecological Indicators, 63, 1-13

34

Bray, J., Johns, N., and Kilburn, D. 2011. An exploratory study into the factors impeding ethical consumption. Journal of Business Ethics, 98(4), 597-608

Chandrakumar, C., M cLaren, S.J. 2018. Towards a comprehensive absolute sustainability assessment method for effective Earth system governance: Defining key environmental indicators using an enhanced-DPSIR framework 
1 Clift, R., Sim, S., King, H., Chenoweth, H.K., Christie, I., Clavreul, J., Mueller, C., Posthuma, L. 2017.

2 The Challenges of Applying Planetary Boundaries as a Basis for Strategic Decision-Making in

3 Companies with Global Supply Chains. Sustainability, 9, 279

4 Clune, S., Crossin, E., Verghese, K. 2017. Systematic review of greenhouse gas emissions for different

5 fresh food categories. Journal of Cleaner Production, 140, 766-783

6 Department for Environment, Food and Rural Affairs and the Forestry Commission. 2006. Sustainable

7 Consumption and Production: Encouraging Sustainable Consumption. Retrieved from

8 http://archive.defra.gov.uk/corporate/about/reports/documents/2006deptreport.pdf

9 Dong, Y., Hauschild, M. 2017. Indicators for environmental sustainability. The 24th CIRP Conference

10 on Life Cycle Engineering

11 Freon, P., Avadi, A., Vinatea Chavez, R. A., Iriarte Ahon, F. 2014. Life cycle assessment of the Peruvian

12 industrial anchoveta fleet: boundary setting in life cycle inventory analyses of complex and plural

13 means of production. LCA for energy systems and food products, 19, 1068-1086

Friedl, S. 2017. What is eutrophication? Causes and effects. Lesson 12, Chapter 15. Study.com

16 Available at: http://study.com (accessed 2 May 2017)

17 Furman, E., Pihlajamäki, M., Välipakka, P., and M yrberg, K. 2014. The Baltic Sea. Environment and

18 Ecology. European MSP Platform

Geels, F., and Schot, J. 2010. Transitions to Sustainable Development: New Directions in the Study of Long Term Transformative Change. In Part I: The Dynamics of Transitions: a Socio-technical

21 Perspective. Routledge, New York, 1-101

Haggrén, G., Halinen, P., Lavento, M., Raninen, S., and Wessman, A. 2015. M uinaisuutemme jäljet. Suomen esi- ja varhaishistoria kivikaudelta keskiajalle. Gaudeamus Oy. ISBN 978-952-495-363-4

Helenius, G. 2010. Processing chain of waste fish and carbon footprint. M aster's Thesis.

25 Lappeenranta University of Technology

Hughner, R. S., M cDonagh, P., Prothero, A., Shultz, C. J., and Stanton, J. 2007. Who are organic food consumers? A compilation and review of why people purchase organic food. Journal of consumer behaviour, 6(2-3), 94-110

Huijben, J., Verbong, G., and Podoynitsyna, K. 2016. M ainstreaming solar: Stretching the regulatory regime through business model innovation. Environmental Innovation and Societal Transitions, 20,

$31 \quad 1-15$

Iho, A., Ahtiainen, H., Artell, J., Heikinheimo, O., and Kauppila, P. 2017. The Role of Fisheries in Optimal Eutrophication M anagement. Water Economics and Policy, 3 (2), pp. 1-27 IPCC. Guidelines for national greenhouse gas inventories. In Agriculture, forestry and other land use, vol. 4; 2006. http:// www.ipcc-nggip.iges.or.jp/public/2006gl/vol4.html

ISO International Organization for Standards. EN ISO 14040. 2006. Environmental management. Life cycle assessment. Principles and framework 
1

ISO 14049. International Organization for Standardization. ISO/TR 14049:2000.

Environmental management, Life cycle assessment, Examples of application of ISO

14041 to goal and scope definition and inventory analysis.

Joshi, J. and Rahman, Z. 2015. Factors Affecting Green Purchase Behaviour and Future Research Directions. International Strategic Management Review, 3, 128-143

Karjalainen, J., M iserquet, D., Huuskonen, H. 1997. The estimation of food consumption in larval and juvenile fish: experimental evaluation of bioenergetics models. Journal of Fish Biology 51, pp. 39-51

Kontula, T., Raunio, A. 2013. Assessment of threatened habitat types in Finland. Available at: http://www.ymparisto.fi/en

US/Nature/Natural_habitats/Assessment_of_threatened_habitat_types_in_Finland (accessed 15 March 2017)

Laso, J., Vazquez-Rowe, I., M argallo, M., Crujeiras, R. M. Irabien, A., Aldaco, R. 2018. Life cycle assessment of European anchovy (Engraulis encrasicolus) landed by purse seine vessels in northern Spain. International J ournal of Life Cycle Assessment, 23, 1107-1125.

LUKE. Natural Resources Institute Finland. 2015. Fisheries and hunting statistics. Available at: http://stat.luke.fi/en/kala-ja-riista (accessed $20 \mathrm{M}$ arch 2017)

Magerholm Fet, A., Schau, E., M., and Haskins, C. 2010. A Framework for Environmental Analyses of Fish Food Production Systems Based on Systems Engineering Principles. Systems Engineering 13 (2)

Møller, J., Boldrin, A., Christenssen, T. H. 2009. Anaerobic digestion and digestate use: accounting of greenhouse gases and global warming contributions. Waste Management and Research, 27 pp. 813824

M yllymaa, T., M oliis, K., Tohka, A., Rantanen, P., Ollikainen, M., Dahlbo, H. Jätteiden kierrätyksen ja polton käsittelyketjujen ympäristökuormitus ja kustannukset. Inventaarioraportti. Finnish Environmental Institute; 2008. http:// www.ymparisto.fi/dow nload.asp? contentid¹/492262

Mäkinen, T. 2008. Voidaanko kalastuksella vähentää kalankasvatuksen ravinnekuormaa? Kalankasvatuksen nettokuormitusjärjestelmän esiselvitys. Riista- ja Kalatalous, Selvityksiä, Helsinki, Finland

Nelleman, C., Macdevette, M., Manders, T., Elickhout, B., Svihus, B., Gerdiens-Prins, A., and Kaltenborn, B. (Eds.). 2009. The environmental food crises. The environment's role in averting future food crises, A UNEP rapid response assessment. UNEP Grid Arendal

Niinimäki, T. and Niinimäki, J. 2008. Rehevöityneiden järven ravintoketjukunnostus ja hoito.

Available at:

http://www.puhdasvesijarvi.fi/easydata/customers/ puhdasvesijarvi/files/jarvihoi/materiaalit/jarvien _kunnostus_ja_hoito.pdf (accessed 30 April 2017)

Nijdam, D., Rood, T., and Westhoek, H. 2012. The price of protein: Review of land use and carbon footprint assessments of animal food products and their substitutes. Food Policy 37, pp. 760-770.

NutriTrade. Available at: http:// nutritradebaltic.eu/ (accessed 25 April 2017) 
15

Randelli, F. and Rocchi, B. 2016. Analyzing the role of consumers within technological innovation systems: The case of alternative food networks. Environmental Innovation and Societal Transitions, 2-13.

Rasi, S. et al. 2012. From Waste to Traffic Fuel -projects. Final Report. Available at:

http://www.mtt.fi/mttraportti/pdf/mttraportti50.pdf

Reed, D.C., Slomp, C.P., and Gustafsson, B.G. 2011. Sedimentary phosphorous dynamics and the evolution of bottom-water hypoxia: A coupled benthis-pelagic model of a coastal system. Limnology and Oceanography 56 (3), pp. 1075-1092

Riva, C., Orzi, V., Carozzi, M., D'Imporzano, G., Adani, F. (2016). Short-term experiments in using digestate products as substitutes for mineral $(\mathrm{N})$ fertilizer: Agronomic performance, odours, and ammonia emission impacts. Science of the Total Environment 547, pp. 206-214.

Rockström, J. et al. 2009. A safe operating space for humanity. Nature 461, pp. 472-475

Ruuhijärvi, J. Olin, M., and M alinen, T. 2014. Ravintoketjukunnostus vesien ja kalakantojen hoidossa. Vesistökunnostusverkoston seminaari, 11-12 June 2014, lisalmi, Finland

Ryberg, M. W., Owsianiak, M., Richardson , K., Hauschild, M. Z. 2016. Challenges in implementing a Planetary Boundaries based Life-Cycle Impact Assessment methodology. Journal of Cleaner Production, 139, 450-459

Sala, S. \& Goralczyk, M. (2013). Chemical Footprint: A Methodological Framework for Bridging Life Cycle Assessment and Planetary Boundaries for Chemical Pollution.

Integrated Environmental Assessment and Management. 9 (4): 623-632.

Sarvilinna, A. 2010. Rehevöityneen järven kunnostus ja hoito. Available at: http://www.vanajavesi.fi/onnimonni/wp-content/uploads/2013/12/jarvikunnostusopas.pdf (accessed 12 April 2017)

Schau, E. M., Ellingsen, H., Endal, A., Aanondsen, S. A. 2009. Energy consumption in the Norwegian fisheries. Journal of Cleaner Production 17 (3) pp. 325-334

Schreckenbach K., Knösche R., and Ebert K. 2001. Nutrient and energy content of freshwater fishes. Journal of Applied Ichthyology. 17 pp.142-144

Setälä, J., Tarkki, V., M annerla, M., and Vielma, J. 2011. Vajaasti hyödynnetyn kalan kaupalliset käyttömahdollisuudet. Available at:

http://www.rktl.fi/www/uploads/pdf/uudet\%20julkaisut/tyoraportit/vajaasti_hyodynnetty.pdf (accessed 20 April 2017)

Silvenius, F., and Grönroos, J. Fish farming and the environment. Results of inventory analysis. Available at: https://helda.helsinki.fi/bitstream/handle/10138/41033/SYKEmo_276.pdf? sequence=3 (accessed 23 April 2017)

Stanek, M., and Janicki, B. 2011. Impact of season and sex on calcium and phosphorus content in the meat of roach (Rutilus rutilus L.) from the Brda River (Poland, Bydgoszcz). Folia Biologica 59 (3-4) 
Steffen, W., Richardson, K., Rockström, J., Cornell, S.E. Fetzer, I. et al. 2015. Planetary boundaries: guiding human development on a changing planet. Science 2015

Sundin, G., Peters, G., Svanström, M. 2015. Using the planetary boundaries framework for setting impact-reduction targets in LCA contexts. International Journal of Life Cycle Assessment, 20, 1684-1700

Svanes, E., Vold, M., Hanssen, O.J. 2011. Effect of different allocation methods on LCA results of products from wild-caught fish and on the use of such results. The International Journal of Life Cycle Assessment. 2011, 16 (6), pp. 512-521.

Svensson, M. 2014. Sustainable resource use of common bream and roach catch from reduction fishing in Östergötland. Uppsala Universitet. Available at: https:// www.divaportal.org/smash/get/diva2:729339/FULLTEXT01.pdf (accessed 10.05.2017)

Tan, R.R., Culaba, A. B. Estimating the carbon footprint of tuna fisheries. 2009.

Center for Engineering and Sustainable Development Research, De La Salle University, M anila Philippines. Available at: http://assets.panda.org (accessed 15 M ay 2017)

Thrane, M . 2006. LCA of Danish Fish Products. New methods and insights. International Journal of Life Cycle Assessment. 2006, 11 (1), pp. 66-74

Thrane, M., Holm Nielsen, E., Christensen, P. 2009A. Cleaner production in Danish fish processing experiences, status and possible future strategies. Journal of Cleaner Production 2009, 17 (3), pp. 380-390.

Thrane, M., Ziegler, F., Sonesson, U. 2009(B). Eco-labelling of wild-caught seafood products. Journal of Cleaner Production 2009, 17 (3), pp. 416-423.

Tiainen, J. et al. 2015. The 2015 Red List of Finnish Bird Species. Ministry of the Environment, Finnish Environment Institute.

Truffer, B. and Coenen, L. 2012. Environmental innovation and sustainability transitions in regional studies. Regional Studies, 46 (1), pp. 1-21

Uusitalo, V., Havukainen, J., M anninen, K., Höhn, J., Lehtonen, E., Rasi, S., Soukka, R., Horttanainen, M. 2014A. Carbon footprint of selected biomass to biogas production chains and GHG reduction potential in transportation use. Renewable Energy, 66 90-98.

Uusitalo, V., Väisänen, S., Havukainen, J., Soukka, R., Luoranen, M. 2014B. Carbon footprint of renewable diesel from palm oil, jatropha oil and rapeseed oil. Renewable Energy 69, 103-113.

YTV. 2010. Biojätteen käsittelyvaihtoehdot pääkaupunkiseudulla. Kasvihuonekaasupäästöjen vertailu. YTV Pääkaupunkiseudun yhteistyövaltuuskunta, Helsinki, Finland

Van Doorn, J. and Verhoef, P.C. 2015. Drivers of and Barriers to Organic Purchase Behavior. Journal of Retailing, 91 (3), pp. 436-450

Vazquez-Rowe, I., Larrae-Gallegos, G., Villanueva-Rey, P., Gilardino, A. 2017. Climate change mitigation opportunities based on carbon footprint estimates of dietary patterns in Peru. Plos One 
1 Whitson D., Ozkaya H. E. and Roxas J., 2014. Changes in consumer segments and preferences to green

2 labelling. International Journal of Consumer Studies 38(5), pp. 458-466

3 Winther, U., Ziegler, F., Skontorp Hognes, E., Emanuelsson, A., Sund, V., Ellingsen, H. 2009. Carbon 4 footprint and energy use of Norwegian seafood products. SINTEF report.

5 Wolf, A., Gondran, N., Brodlag, C. 2017. Detecting unsustainable pressures exerted on biodiversity

6 by a company. Application to the food portfolio of a retailer. Journal of Cleaner Production, 2017, 7 166, pp. 784-797.

8 Yang, Y., Heijung, R. 2017. On the use of different models for consequential life cycle assessment. 9 International Journal of Life Cycle Assessment, 23,751-758.

10 Ziegler, F., Hornborg, S., Green, B.S., Eigaard, O. R., Farmery, A. K. 2016. Expanding the concept of

11 sustainable seafood using Life Cycle Assessment. Fish and Fisheries, 17, 1073-1093. 